about six miles' (Phil. Trans. R.S., vol. clxriii. p. 289 ; quoted on p. 308 of Darwin's 'Coral Reefs,' third edition). Here he evidently refers to the shallow water extending on all sides to the Ioo-fathom line, where there is about that depth a sudden fall. The fact is, such a character belongs to a large number of oceanic islands, whether surrounder by fringing reefs or no reefs whatever, and is clue to quite other causes than reef-building."

$$
\text { June I4. }
$$

H. B. G.

\section{The Fireball of May 29, I889.}

THE fireball which I mentioned in NATURE of June I 3 (p. I 50 ) as having been seen at Leeds on May 29, was alsi) observed at Belfast by Mr. I. W. Ward, who recorded the latter part of its course as from Vega to $\alpha$ Cygni.

Comparing this path with that assigned by Mr. D. Booth at Leeds, I find the radiant point at $2142^{\circ}-7^{\circ}$, which was in azimuth $\mathrm{II}^{\circ}$ (west of south), and altitude $281^{\circ}$ at the time (10h. $45 \mathrm{~m}$.) of observation.

When first seen at Leeds the fireball was situated over a point in the Irish Sea, in lat. $53^{\circ} 58^{\prime} \mathrm{N}$., long. $5^{\circ} 22^{\prime} \mathrm{W}$., and it height was sixty-one miles. At its disappearance it was six miles west-south-west of Stranraer on the coast of Wigtown, Scotland, at a height of twenty-five miles. The earth point was ten miles west of Troon, Ayrshire. The real length of path traversed was seventy-five miles, and the velocity eight and a third miles per second deduced from the estimated time of flight (nine seconds) at Leeds.

The radiant point at $2 \times 14^{\circ}-7^{\circ}$ in Libra is situated near the earth's anti-apex, and the motion of the fireball would therefore be extremely slow, as it must have overtaken the earth in her orbit. It is curious that several doubly-observed meteors which have made their apparitions in the spring months have given the same radiant point. Thus the large fireball of May 12, 1878, seen in Scotland and the north of England had a radiant at $214^{\circ}-7^{\circ}$ (Prof. A. S. Herschel). The conspicuous meteor of April 2I, I889, observed by Prof. Herschel at Croydon and the writer at Bristol, had a radiant at $218^{\circ}-5^{\circ}$. The vernal months appear to furnish us with a long-enduring shower from this special region of the zodiac.

Bristol, June 15 .

W. F. DENNING.

Meteor.

ABout II.30 p.m. on the night of June r 3, the sky being partially covered with fleecy clouds slowly drifting from the south-west, so that the full moon was frequently obscured, a shooting-star appeared in the nortb, at an elevation of about $50^{\circ}$ to $60^{\circ}$, and descended obliquely towards the east. It was as bright as a star of the first magnitude, and was visible during a slightly zigzag flight of some $30^{\circ}$, leaving no trail. But the remarkable thing was that the sky in that quarter was pretty closely covered with the slowly-moving fleecy clouds, so that no fixed stars were visible. The meteor, therefore, must have been below the clouds, at least in the latter part of its course.

Birstal Hill, L.eicester.

F. T. Мотт.

\section{Stationary Dust-Whir1.}

YESTERDAY morning, at 9.30, I was fortunate in witnessing a stationary dust-whirl, about a hundred yards from where I stood, on a dust-covered highway lying due east and west. The morning was warm, $67^{\circ} .5$ in the shade, barometer at $30^{\circ} \circ 6$, and the sky clear, excepting a few isolated cumulus patches. The air was still, the wind-vane indicating north-west. The appearance of the whirl presented a resemblance to a fountain of water playing, only the base was broader than the upper part, which was perfectly columnar. It remained, for nearly five minutes, absolutely stationary, then suddenly ceased, recommencing for a few seconds, on a much smaller scale, some ten yards westwards. Its height, when at its best, would be about 25 feet, and its diameter, midway, 2 feet. I could not correctly ascertain the spiral motions of the whirl, but judged the outer spiral to move from right to left, and upwards. The wind jum ped round into the north-east shortly afterwards, with clear sky, and the barometer steadily rising. No others were seen during the day.

Driffield, June 17 .

J. LOVEL.

\section{Bunsen's Photometer.}

IF we place the "grease-spot" screen between two sources of light, situated at $A$ and $B$, whose intensities are $I$ and $I^{\prime}$ re- spectively, and if $\mathrm{C}$ be the position of the screen for which the spot disappears when viewed from the side towards $\mathrm{A}$, and $\mathrm{C}^{\prime}$ the corresponding position when viewed from the other side, it is usual to say : Take the mean of $\mathrm{AC}$ and $\mathrm{AC}^{\prime}$, and the mean of $\mathrm{BC}$ and $\mathrm{BC}^{\prime}$; the squares of the means will be approximately proportional to the intensities.

The relation

$$
\frac{\mathrm{I}}{\mathrm{I}^{\prime}}=\frac{\mathrm{AC} \cdot \mathrm{AC}^{\prime}}{\mathrm{BC} \cdot \mathrm{BC}^{\prime}}
$$

is more exact, as may be shown by the following :- -

Let $a$ be the fraction of the light falling on unit area of the spot from $\mathrm{A}$ which reaches the eye, and $b$ the corresponding fraction for the dry part; and let $c$ and $d$ be the respective fractions of the light falling on the other side of the paper, which, after passing through, reach the eye. Then, since the spot and the dry part in the position $C$ are equally bright when viewed from the side towards A, we have, equating the light per unit area from the two parts.or

$$
\begin{aligned}
\frac{\mathrm{I}}{\mathrm{AC}^{2}} a+\frac{\mathrm{I}^{\prime}}{\mathrm{BC}^{2}} c= & \frac{\mathrm{I}}{\mathrm{AC}^{2}} b+\frac{\mathrm{I}^{\prime}}{\mathrm{BC}^{2}} d, \\
\mathrm{I} & (a-b)=\frac{\mathrm{I}^{\prime}}{\mathrm{BC}^{2}}(d-c) \cdot \ldots . .(1)
\end{aligned}
$$

If $\mathrm{C}^{\prime}$ be the position of the screen for which the parts appear equally bright, as seen from the other side, we have-

or

$$
\begin{aligned}
\frac{\mathrm{I}}{\mathrm{AC}^{\prime \prime 2}} c+\frac{\mathrm{I}^{\prime}}{\mathrm{BC}^{\prime 2}} a & =\frac{\mathrm{I}}{\mathrm{AC}^{\prime 2}} d+\frac{\mathrm{I}^{\prime}}{\mathrm{BC}^{\prime 2}} b, \\
\frac{\mathrm{I}^{\prime}}{\mathrm{BC}^{\prime \prime 2}}(a-b) & =\frac{\mathrm{I}}{\mathrm{AC}^{\prime \prime 2}}(d-c) \ldots . .
\end{aligned}
$$

From (I) and (2)-

$$
\frac{\mathrm{I}}{\mathrm{I}^{\prime}}=\frac{\mathrm{AC} \cdot \Delta \mathrm{C}^{\prime}}{\mathrm{B} \overline{\mathrm{C}} \cdot \overline{\mathrm{BC}}^{\prime}} .
$$

If $a+c=b+d$, we see that $\mathrm{C}$ and $\mathrm{C}^{\prime}$ must coincide. This condition implies that the light lost is the same for the spot and for its surroundings.

In the method of using the photometer, in which the two lights to be compared are balanced successively against a third light, and the spot in both cases is viewed from the same side, the inequality of the portions of light lost by the two parts does not disturb the result.

University College, Bangor, June 6.

D. M. LEwis.

\section{THE TUTICORIN PEARL FISHERY.}

A FTER an interval of more than twenty-seven years, A the pearl-oyster (Avicula fucata, Gould) has pro duced pearls off the Madras coast of the Gulf of Manaar, in sufficient quantities to be worth the expense of fishing. The last fishery of the Tuticorin banks took place in the years $1860-62$, and resulted in a net profit to Govermment of Rs. 3,79,297 ( $₫ 37,929$ at par). In olden times, when Tuticorin was in the possession of the Portuguese and Dutch, the fishery used to be carried on much more frequently than it is at the present day, and a difficult problem, which remains to be solved, is, What are the causes of the decline of the pearl fishery, and how can the Tuticorin banks be made to yield a more frequent harvest? Whether the baneful influence of the Mollusca known locally as sooram and killikoy (Modiota sp., and Avicula sp.), the ravages of the file-fishes (Balistes) and Rays (Trygon, \&c.), poaching, or currents, are responsible for the non-production of an abundant crop of adult pearl-producing oysters during more than a quarter of a century, it would be impossible to decide until our knowledge of the conditions under which the pearloysters breed, develop, and live, is more precise than it is at present.

Superstition, as of old, still clings to the native divers; and $I$ read, in a recent issue of the Times of Ceylon, that "at present there are said to be I 50 boats, with their full complement of men, all waiting at Kilakarai in readiness 
to proceed to Dutch Bay, but they will not leave until after some festivities which occur on the I 5 th instant, when it is customary for them to pray for protection from sharks, \&c., while engaged in diving." I can find no record of a diver being killed, in recent years, by a shark. But a case is cited, in which a native died at Tuticorin from the poisonous stings of a jelly-fish. At certain seasons of the year, jelly-fish are very abundant in the Tuticorin harbour, and a resident merchant tells me that, so great is the dread of them among the natives, that he has kncwn coolies, engaged in carrying loads of palmyra jaggery through the shallow water to the cargo-boats, refuse to enter the water till a track free from jelly-fish was cleared for them by two canoes dragging a net between them.

The pearl-bank which is being fished at the present time, is known as the "Tholayiram Par," which covers an area of about five square miles, and lies more than ten miles east of Tuticorin, in from 8 to $10 \frac{1}{2}$ fathoms. The following record, by the Superintendent of the Pearl Banks, shows the condition of this bank as regards oyster-supply from the year I860 to I884, the oysters which are now being obtained having been first noticed at an early stage of growth in the latter year:- -

A pril r 860 .- Plenty of oysters three and a half years old.

November 1861. - Oysters scarce; nearly all gone.

April 1863.-Sooram and killikoy with some young oysters.

November 1865 to A pril 1869.-Blank.

March I871.--Five oysters with a quantity of soorcm.

February 1872.- Five oysters of three years old found.

May 1873.-Three oysters found.

January 1875 . - Three oysters of two years old found.

March I 876. - North part blank.

April 1877. - South part blank.

April I878. - Thickly stocked with oysters one year old.

May I879.--Blank.

May i $880 .-B l a n k$.

May 1881.- - Some oysters mixed with killiken.

May 1882.- No oysters; dead shells and soirim.

April 1883.- Three oysters found.

March 1884.-Plenty of oysters one year old; clean and healthy.

This record shows very clearly how capricious is the life of the pearl-oyster, how easily the hopes of a productive bank may be banished (witness the total disappearance of the oysters in 1879), and points to the evil influence of sooram, which, spreading in dense masses along the rocky bottom, crowds out the young pearloysters.

Since 1884, the "Tholayiram Par" has been carefully watched, and the growth of the oyster, from the young to the adult stage, has steadily advanced.

\begin{tabular}{|c|c|c|c|c|}
\hline \multicolumn{2}{|c|}{ Ten oysters lifted } & March i 884 , & weighed & I \\
\hline , & ", & October 1884 , & $"$ & $3 \frac{3}{4}$ \\
\hline$"$ & ", & March 1885, & , , & $6 \frac{1}{4}$ \\
\hline$"$ & " & October I885, & , & 7 \\
\hline 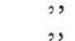 & ," & $\begin{array}{l}\text { April I886, } \\
\text { November } 1886 \text {, }\end{array}$ & :, & $\begin{array}{l}7 \frac{2}{2} \\
8 \frac{1}{2}\end{array}$ \\
\hline ", & ," & March 1887 & ," & $10_{4}^{\frac{2}{3}}$ \\
\hline , & ," & October 1887 , & " & 13 \\
\hline , & ", & November I888, & ," & $15^{\frac{1}{t}}$ \\
\hline
\end{tabular}

In November last, I 5,000 oysters were taken from the bank for the purpose of valuation by pearl-merchants, and the product was valued at Rs. I $3,12,8$ per 1000 oysters.

The shells of the oysters which are now being brought in daily are incrusted with various marine animals (Sponges, Polyzoa, \&c.), and enveloped in masses of delicate Algæ; but, among very many thousands which I have examined, I have met with no sooram, and only very few specimens of killikoy. The oysters are living either on sand, by which they are partially buried, or on coral rocky ground (Turbinaria, Montipora, Porites, \&c.), and are often brought up attached by their byssus to dead branches of Madrepores, or Melobesinn nodules. Large specimens of the big anai mullu shanku (Murex sp.) are frequently brought up by the divers, and the tough animal, when removed from the shell, is served up for the evening meal.

The improvised camp, from which the fishery is conducted, is situated on the coast about two miles north of Tuticorin, and, on the way thither across a long stretch of sand, the kilns in which coral and shells are converted into chunam are passed, and the chank godowns, in which the chanks (Turbinella rapa), whose shells afford an annual source of revenue to Government, are stored, the animal matter being got rid of by the combined influence of insects and bacteria. The camp, which is built of bamboo and palmyra, is made up of residential huts, tents, and bungalows, offices (treasury, dispensary, \&c.), sheds called kottoos, in which the oysters are counted and submitted to the unsavoury washing process, and the native basarr, gaily decorated with flags, in which the product of the oysters is exposed for sale.

As soon after mianight as the land wind sets in, the signal gun is fired on the shore by the native beach master, and, amid a good deal of shouting, all sail is set, and the fleet, which is unfortunately composed of less than fifty boats, with its complement of divers, makes for the bank, which should be reached by daylight. The hoisting of a flag on the schooner which is stationed on the bank is the signal for the day's fishery to commence. The limits of the entire bank are marked out by buoys, and the divers are supposed only to work, on any given day, over an area which is also indicated by buoys; but, owing to adverse winds and other causes, it is sometimes found impossible to keep the boats within the prescribed area. A stone, to which a rope is attached, is put over the boat's side, and a basket or net fastened in a similar way. These ropes the diver takes in one hand, and, placing one foot on the stone, he draws in a deep breath, closing his nostrils with his other hand; or the nose is inserted into a clip, which tightly compresses the nostrils. At a given signal the ropes are let go, and the diver descends to the bottom. The slacking of the ropes shows that this is reached. The diver then lets go the stone, which is drawn up to the surface, and, after filling the basket or net with oysters, he ascends to the surface to regain his breath. The divers work in couples, two to each stone, and the oysters brought up are kept carefully separated from those of other divers. The other day 237,000 oysters were brought up by 454 divers, in about $5 \frac{1}{3}$ hours, giving an average of 524 oysters to each diver. A European diver is engaged experimentally on the bank, but his greatest haul in a day has been only I joo oysters.

The diving operations cease for the day about I.30 p.m., and the boats start for the land, the signal gun being fired and the Union Jack run up on the flagstaff as soon as they are sighted. On reaching the shore the boats are secured, the oysters carried to the shed, rapidly counted, and divided into three heaps. The superintendent of the fishery, or some other responsible officer, touches with his stick one of these heaps, which becomes the property of the divers, who receive a pass and carry their hardgained earnings outside the shed, where a swarming crowd of natives is waiting, eager to try their luck by purchasing a few oysters at a rate varying from about fifteen to forty for a rupee. Until long after dark crowds of natives may be seen squatting in circles on the sand, opening their oysters and carefully examining the flesh with a knife in search of even the smallest pearls. The utmost good temper prevails, and the possessor of only a few seed pearls is, apparently, perfectly happy. The two heaps which are left by the divers constitute the Government share, and are carefully counted by Government coolies. The beating of the tom-tom then announces that the Government auction is about to commence. The oysters are put up for sale in lots of 1000 , and the 
purchaser has the option of taking a certain number of thousands at the same rate. As soon as the purchase money has been paid, the oysters are handed over to the purchaser, who sends them off by train, or deposits them in the kottoo at the northern end of the camp, where various natural agents bring about the requisite process of dissolution of the animal matter. After some days the residue is carefully washed, the prevailing maggots skimmed off, and a careful search made for the pearls.

Pearl Camp. EDGAR THURSTON.

\section{CALIFORNIAN FORESTRY.}

$\mathrm{I}^{\mathrm{T}}$ is matter for great satisfaction to learn that the "people of the State of California represented in Senate and Assembly" have created a Board of Forestry for the purpose of collecting and diffusing information with regard to forestry, tree-culture, and tree-preservation. The readers of NATUR: will not fail to appreciate the economic significance of wisely administered forest laws so far as those laws are based upon scientific knowledge, and there are special reasons why they should feel an interest in the forests of the Pacific slope. They will consequently be glad to learn from the second biennial Report of the State Board of Forestry now before us that whereas, "under the old conditions, waste, destruction, and violation of law were rife, ... the activity of the Board in attempting a reform, and the consequent investigations of the Government, have had a most gratifying result." Fires have been reduced in frequency and extent, watersheds and springs have been protected, slopes saved from further denudation, and replanting effected. It seems strange that, with so great a wealth of native trees, replanting should have become necessary, and still more that the Eucalypts of Australia should be preferred for this purpose to the pines of the Sierras. Nevertheless there are many sites where drought-resisting trees are specially required, and in which some of the Eucalypts, such as viminalis and corynocalyx, do better than the pines. Experimental stations have been established under different conditions of soil and climate, survey-maps have been constructed, while in the Report now before us a beginning has been made of a scientific and popular description of the forest trees of California. The preparation of this catalogue has been intrusted to Mr. J. G. Lemmon; its illustration will be undertaken by Mrs. Lemmon, and by photographs. For botanical purposes the writings of Engelmann, Sargent, Watson, Parry, and others in recent times, of Sir W. Hooker and Dr. Arnott at a more remote period, will supply what is needed.

Mr. Lemmon waxes enthusiastic, as well he may, over the forests of California. Pre-eminent over all forestal regions of the earth are the dense and extensive tree-growths clothing the slopes of that most diversified and wonderful of mountain-ranges - the Sierra Nevada of Western America - a range distinguished by the abruptness of its majestic uprise from the plain, the splintered and rough-hewn forms of its thousand peaks, the high elevation of their pinnacles ever bearing their crowns of snow, but most of all pre-eminent for its bounteous and beautiful "enrobing forest,... the noblest in North America, perforated atong its raised centre-line by a thousand peaks rising through the mantle into perpetual winter; while both slopes, east and west, are rent by a million valleys, depressed through the robe (of forest) into the middle region of changing seasons, and the fringe of the garment trails out over the domain of almost perpertual summer." In a similar strain Mr. Lemmon proceeds at considerable length and in a style we are not accustomed to meet with in "Blue-books." The Sierra forests, so far as environment is concerned, occupy a middle position between torrid and frigid conditions. They are composed mainly of evergreen trees, not one of which is specifically identical with the trees on the Atlantic side of the Continent, though often so curiously alike that each genus has its "representative species" on either side. The "big trees," Sequoia gigantea, or Wellingtonia, have been written about so often that most people are familiar with them. "Far excelling them in loveliness" are the four species of Abies -nobilis, grandis, magnifica, and concolor. These are all, with many others, cultivated in our parks and gardens, where they thrive better as a rule than in the Eastern States of America. Already they justify in a measure Mr. Lemmon's ecstasies; though it is probable that their beauty will not be enhanced as they grow old, for many of these trees which are pictures of grace and beauty when young become "scraggy" and unlovely when old. Fortunately the standard of age is different in trees and men, and some generations of men may pass before the trees lose their charm. Of their value as timber trees in this country we need not speak here ; indeed, little definite is yet known ; but, at any rate, there are well-founded hopes in the case of the Douglas fir, the Nootka Sound cypress, Thuya borealis, the Thuja gigantea, and some others which seem destined to play an important part in the forestry of the future.

After some generalities Mr. Lemmon proceeds to give a classification of the true pines (Pinus), of the Pacific slope, a classification intended for popular purposes, and therefore one in which the histological characters of the leaves are passed over. The main divisions are into smooth-coned pines and rough-coned pines, corresponding to the sections Strobus and Pinaster respectively. In the one the scales of the cone end in thick, prominent, often spiny bosses, in the other the ends of the scale are nearly flat or project but little. Then comes a subdivision according to the length of the cone, surely a most untrustworthy criterion; for instance, Lambert's pine, the gigantic sugar pine, bears cones varying from Io to 22 inches in length according to Mr. Lemmon's own showing. Further subdivisions are founded on the position of the young cone near the terminal leaf-bud or at some distance from it, on the length of time the cones remain on the tree, the way in which the scales eventually separate, and so forth. Having characterized the various species of Pinus, the author proceeds to give detailed information about each. This is the most valuable portion of Mr. Lemmon's report for European botanists. We would fain make many quotations, but our space allows us only to mention two species. The magnificent sugar-pine (Lambertiana), was first made known by Douglas. It sends up a magnificent shaft two hundred feet high, and sometimes much more. The value of this tree for "lumber" purposes is as great as its stateliness is imposing, hence thousands of noble trees have been shamefully destroyed. "Lawless vagabonds penetrate the Sierra forests with only the equipment of an axe and a long saw, and, levelling these monstrous trees, they saw out a cut, examine it, and perchance move on to the destruction of others, leaving to rot on the ground trees that would yield to the careful lumberman twenty thousand to fifty thousand feet of clear lumber, worth hundreds of dollars." Pimus Torreyana, the lone pine, also deserves special notice here as a species of much structural interest, and as one which, it appears, is on the high road to extinction, unless that process can be obviated by forest ordinances or by the care of the cultivator. On the coast of Southern California, on the bluffs at Del Mar, San Diego County, within a range of four miles only, and nowhere else so far as known, are a few small trees, buffeted and often prostrated by ocean winds, clinging to the face of crumbling yellow sandstone. On the sheltered inner side of the hills and on the spurs of the cañons, bathed with frequent sea-fog, the trces have indeed, a better chance, and they accordingly there form a trunk some thirty or even fifty feet in height, 